\title{
Integrating the Kano model for optimising CPR-D training system
}

\author{
Jingjing Liu*
}

School of Nursing, The Navy Medical University, 800, Xiangyin Road, Shanghai, China

Email: jj_ddup@126.com

*Corresponding author

\section{Huijun Xi}

Nursing Department, Changhai Hospital, 168, Changhai Road, Shanghai, China Email: xhj_cn@126.com

\section{Li Gui}

School of Nursing, The Navy Medical University, 800, Xiangyin Road, Shanghai, China Email: guili2000@qq.com

\begin{abstract}
To explore customers' requirements of CPR-D training system and optimise the system accordingly. We conducted a Kano model-based questionnaire survey among medical staffs with 28 quality features of the CPR-D training system being developed earlier. A modified Kano categorisation was adapted to decide the final category. Totally 268 of the 300 questionnaires distributed were valid. Most of the participants were either physicians or nurses, while the rest were non-clinical medical staffs or nursing teachers. Of 28 features, four were attached to attractive attributes, 15 were one-dimensional attributes, seven were indifferent attributes, and one was reversal attribute, while one feature was ambiguous. After the modified Kano categorisation, four were categorised to attractive attributes, 19 were one-dimensional attributes, four were indifferent attributes, and one was reverse attribute. Comprehensively considering the results, version 1.0 of CPR-D training system was upgraded to version 2.0, in which a total of seven QFs were optimised. The Kano model-based questionnaire provides valuable information for optimisation of CPR-D training system. In the future, continuous survey should be conducted to update customers' requirements.
\end{abstract}

Keywords: Kano model; CPR; defibrillation; training.

Reference to this paper should be made as follows: Liu, J., Xi, H. and Gui, L. (2019) 'Integrating the Kano model for optimising CPR-D training system', Int. J. Computational Medicine and Healthcare, Vol. 1, No. 1, pp.59-72. 
Biographical notes: Jingjing Liu is a teacher in the Naval Medical University. She is majoring in Emergency Nursing and Medical Education. In the past several years, she devoted to the training and populisation of CPR, and she has been developed several training systems for medical staff and medical students, and integrated information technology into medical education.

Huijun Xi is the Chief Head Nurse of Changhai Hospital. She is good at emergency rescue and medical training. She is in charge of the training and cultivation of nursing interns in the Changhai hospital.

Li Gui is the Director of the Emergency Nursing Department of the Medical University. She is majoring in emergency cardiovascular care and emergency medical training. She has rich experience in medical education, and has been trying to bring information technology into training of medical staffs in military.

\section{Introduction}

The adoption of new information and communication on technologies in education has brought significant changes in the traditional educational paradigm by promoting new forms of teaching and learning. Computer-based technologies informed by the science of learning are becoming increasingly prevalent in education and training nowadays (Friedl and O'Neil, 2013), which allows more flexibility in teaching, making it more accurate, dynamic and permeable to the requests and needs of the context in which the learner is located (Rodrigues and Peres, 2013). As medical education is complex and challenging, new forms of teaching and learning means a lot. According to one study (Juanes and Ruisoto, 2015), since devices and digital environments based on clinical simulation can play an important role in acquiring competences and clinical skills, the integration of new technologies in the classroom is one of the keys to success in health education. A whole new generation in health science education is being increasingly trained in new technologies, promoting innovation and communication (Lau and Bates, 2004; Lin, 2012; Martínez-Pérez et al., 2015). The European Resuscitation Council Guidelines for Resuscitation published in 2015 recommended that short video/computer self-instruction courses, with minimal or no instructor coaching, combined with hands-on practice can be considered as an effective alternative to instructor-led basic life support (BLS) (CPR and AED) courses (Greif et al., 2015). Considering CPR and defibrillation (CPR-D) are necessary skills for all medical staffs and medical students, the development of training resources for CPR-D skills is important. Thus, we developed a CPR-D training system to train medical staffs of CPR, airway management and defibrillation skills.

In the context of medicine, one of the main challenges of the teaching and learning process is to balance the training resources with the requirements of learners. For this reason, it is important to design training resources adapted to the requirements of the learners (Juanes and Ruisoto, 2015). As recommended, starting a project with a complete set of requirements is not necessary. Having an ordered list of requirements for the first two or three iterations would suffice (Munagavalasa, 2014). To maximise customers' requirements for CPR-D training system and accomplish them accordingly, the requirements mining and ranking are necessary. One of the many techniques available for ranking these requirements is the Kano model (Excite and Delight Your Customers by 
Using the Kano Model, 2014). Kano model is a better tool for determining customer requirements when developing or innovating new product. The Kano model of customer satisfaction classifies product attributes based on how they are perceived by customers and their effect on customer satisfaction. These classifications are useful for guiding design decisions in that they indicate when good is good enough, and when more is better (Kano Model Analysis, 2002). Presently, Kano model has been applied for multiple new product design and innovation for compliance customer need with respect to customer satisfaction (Chen et al., 2009; Rashid et al., 2010; Sireli et al., 2007). Therefore, we conducted a Kano model-based study to explore customers' requirements and upgrade CPR-D training system.

\section{Methods}

This study used a cross-sectional survey. Questionnaire was employed to survey the medical staffs' cognitive feelings about individual quality features (QFs) under both sufficient and insufficient conditions.

\subsection{General information of CPR-D training system}

The CPR-D training system version 1.0 we developed consists of four modules, namely self-evaluation, microlecture, CPR-D game and risk prediction of cardiovascular diseases (CVD). Self-evaluation module contains a library of 167 test questions, in which 25 test questions will be extracted randomly to create a test paper. Microlecture module contains ten videos, each of which is shorter than five minutes and centres on one topic about CPR-D skills, such as BLS skill, Heimlich manoeuvre. CPR-D game simulates a scenario in which the player has to rescue a sudden cardiac arrest (SCA) patient. Risk prediction of CVD module shows an estimation tool to predict the risk to suffer CVD, which helps health professionals to know better of CVD and increase their willingness to learn CPRD skills by estimating their own or patients' risk of CVD.

\subsection{Development of Kano model-based questionnaire}

Based on Kano's model, this study developed a two-dimension QF element evaluation table, and proposes a set of QFs to measure the degree of increase in 'sufficient' and of decrease in 'insufficient' in given quality elements. The Kano model divides product attributes into five categories (Figure 1): attractive attributes (A), one-dimensional attributes $(\mathrm{O})$, must-be attributes $(\mathrm{M})$, indifferent attributes $(\mathrm{I})$, reversal attributes $(\mathrm{R})$, which is valuable for optimising of CPR-D system.

To develop the questionnaire, QFs about the four modules of CPR-D training system were identified. Twenty-two QFs were firstly abstracted by research of relevant literatures and similar education systems. Then a focus group meeting was held, in which three specialists majored in software development, three medical educators, and four medical staffs who had used this system were invited to attend. At last, 28 items with respect to the QFs of the system were identified. On this basis, a Kano model-based questionnaire was developed to address each of these 28 QFs. The questionnaire contains two sections, one of which is socio-demographic information, while the other is QFs. For 
each feature (Table 1), two questions were asked, one of which evaluated the reaction of the participant to the presence (functional form) of the expectations or need, while the other evaluated the reaction of participant to the absence (dysfunctional form) of the expectations or need. Usually, the Kano questionnaire lists two questions of each feature by order. What is more, the items were arranged from easy to difficult. However, it will interfere the choice of the participants due to inertial thinking (Chuanzi, 2013). Thus, in this study, the questions of each feature were rearranged, and all items were arranged randomly.

Figure 1 Kano model

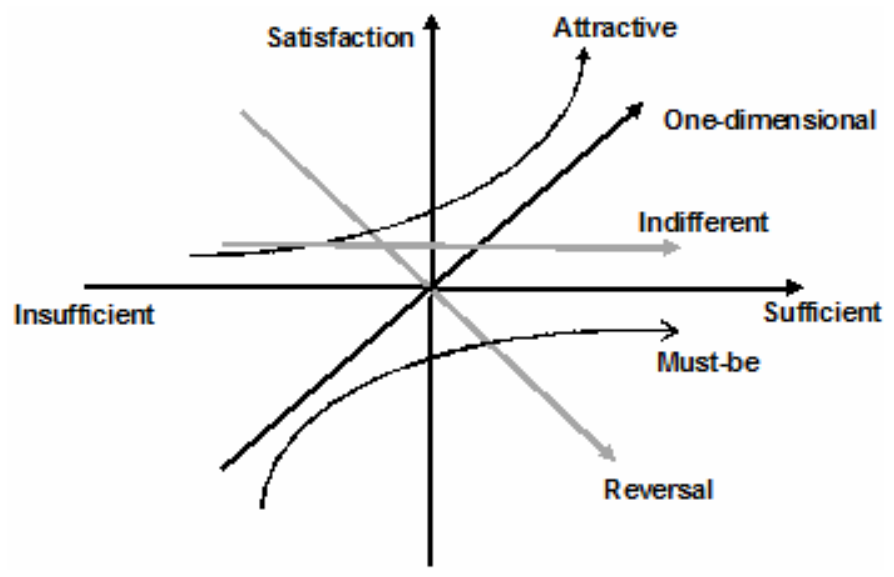

Table 1 Professional evaluation Kano matrix

\begin{tabular}{lccccc}
\hline Lunctional & Like & Must-be & Neutral & Live-with & Dislike \\
\hline Like & $\mathrm{Q}$ & $\mathrm{A}$ & $\mathrm{A}$ & $\mathrm{A}$ & $\mathrm{O}$ \\
Must-be & $\mathrm{R}$ & $\mathrm{I}$ & $\mathrm{I}$ & $\mathrm{I}$ & $\mathrm{M}$ \\
Neutral & $\mathrm{R}$ & $\mathrm{I}$ & $\mathrm{I}$ & $\mathrm{I}$ & $\mathrm{M}$ \\
Live-with & $\mathrm{R}$ & $\mathrm{I}$ & $\mathrm{I}$ & $\mathrm{I}$ & $\mathrm{M}$ \\
Dislike & $\mathrm{R}$ & $\mathrm{R}$ & $\mathrm{R}$ & $\mathrm{R}$ & $\mathrm{Q}$ \\
\hline
\end{tabular}

Notes: $\mathrm{A}=$ attractive, $\mathrm{I}=$ indifferent, $\mathrm{M}=$ must-be, $\mathrm{O}=$ one-dimensional, $\mathrm{Q}=$ questionable and $\mathrm{R}=$ reverse.

\subsection{Participants}

A non-probability, convenience sampling approach was adopted to recruit subjects for the survey. All participants are medical staffs who participated in the continue education program of emergency medicine in the Second Military Medical University, they had used CPR-D training system version 1.0 for CPR-D skills training. A total of 300 medical staffs answered the Kano model-based questionnaire. All participants were invited and they were volunteered to take part in the survey. 


\subsection{Survey}

The Kano model-based questionnaire we developed earlier was used to classify and rank staff preferences regarding to CPR-D training system. The survey was conducted after a CPR-D training, which was held in SMMU for about three hours, and all participants completed the learning of four modules of CPR-D training system. After the training course. In a quiet classroom, the researcher explained the purpose and instruction of this survey to all participants before they filled in the Kano model-based questionnaire, and all questionnaires were retrieved in about $30 \mathrm{~min}$.

\subsection{Data analysis}

Data were entered into SPSS20.0 statistical software. Descriptive statistics including proportions were calculated. The results were evaluated and interpreted according to the answer frequency, and the highest tally/count among the totals of each of these categories for a given requirement was picked as the category for the QF. A one-dimensional chi-square test was applied to the highest and second highest categories to test for significant statistical difference at the $90 \%$ confidence level. Statistical significance was set at $p=0.05$. What is more, the customer satisfaction coefficient indicates the extent to which satisfaction increases if a product requirement is met or the extent to which satisfaction decreases if a product requirement is not met. The coefficient (SI/DSI) were calculated using the formula of Matzler and Hinterhuber (1998) as follows:

$$
\begin{aligned}
& S I(\text { Satisfaction index })=\frac{A+O}{A+O+M+I} \\
& D S I(\text { Dissatisfaction index })=\frac{O+M}{A+O+M+I}
\end{aligned}
$$

\subsection{Ethical considerations}

The study received ethical approval from SMMU, the approval number is 2014LL008. Oral informed consent was obtained from all participants.

\section{Results}

\subsection{Socio-demographic data}

Of the 300 questionnaires distributed, 296 were returned. After excluding the uncompleted or invalid questionnaires, 268 were left. The average age of the participants was $29.13 \pm 7.04$ (range 21-50) years old, all of whom had a clinical experience ranging from 1-31 years (average $6.88 \pm 7.95)$, majority of them $(65.67 \%, n=176)$ held an bachelor's degree, while others had an associated degree or a master's degree. Most of the participants were either physicians $(39.18 \%, \mathrm{n}=105)$ or nurses $(42.54 \%, \mathrm{n}=114)$, while the rest were medical staffs $(18.28 \%, \mathrm{n}=49)$ like laboratorian, pharmacists or nursing teachers. 


\subsection{Categories of the $Q F s$}

Of 28 features of CPR-D training system, four features were attached to attractive attributes, fifteen were one-dimensional attributes, seven were indifferent attributes, and one was reversal attribute, while one feature was ambiguous (Table 2 and Table 3).

Table 2 Categories resulting from the Kano questionnaire

\begin{tabular}{lcc}
\hline Category & Number & Percentage (\%) \\
\hline Attractive attributes (A) & 4 & 14.29 \\
One-dimensional attributes (O) & 15 & 53.57 \\
Must-be attributes (M) & 0 & 0.00 \\
Indifferent attributes (I) & 7 & 25.00 \\
Reversal attributes (R) & 1 & 3.57 \\
Ambiguous preferences & 1 & 3.57 \\
Total & 28 & 100 \\
\hline
\end{tabular}

\subsection{Modified Kano categorisation}

However, in some cases the highest scoring category was only scored a little bit more than the second highest. As some literature reported (Sireli et al., 2007; Abdelhamid, 2013; Wu et al., 2010), the traditional method of assigning Kano categories based on the principles above needs modifying. Thus, in this study, we applied a novel method to categorise those features. A rule stating that 'must-be' category takes priority of assignment over a 'one-dimensional' category, which in turn takes priority over an 'attractive' assignment, which in turn takes priority over an 'indifferent' assignment can be written as $\mathrm{M}>\mathrm{O}>\mathrm{A}>\mathrm{I}$ (Sauerwein et al., 1996). This represents a conservative approach to ensuring that features that may negatively impact customer satisfaction are addressed before those contributing to satisfaction. The modified Kano categories that resulted from using this approach are shown in Table 4.

\subsection{Optimising of CPR-D training system}

A competitive product meets basic attributes, maximises performances attributes, and includes as many 'excitement' attributes (attractive attributes) as possible at a cost the market can bear (Arvindakarthik et al., 2013). According to the principle above, we upgraded CPR-D training system of version 1.0 to version 2.0 (Figure 2) and proposed a detailed plan for future optimising (Table 5). We put one-dimensional QFs that can be easily accomplished as the first priority, while the attractive QFs were ranked as the second priority. Those difficult to accomplish or those which may bring troubles once accomplished were given up. For example, as the reduction of occupied memory will decline video definition, the system should not accomplish the QF of 'small occupied memory'. What is more, the reversal QFs should be avoided. As a result, a total of seven QFs was optimised for CPR-D training system version 2.0. 
Table 3 Aggregate responses to the Kano questionnaire $(\mathrm{n}=268)$

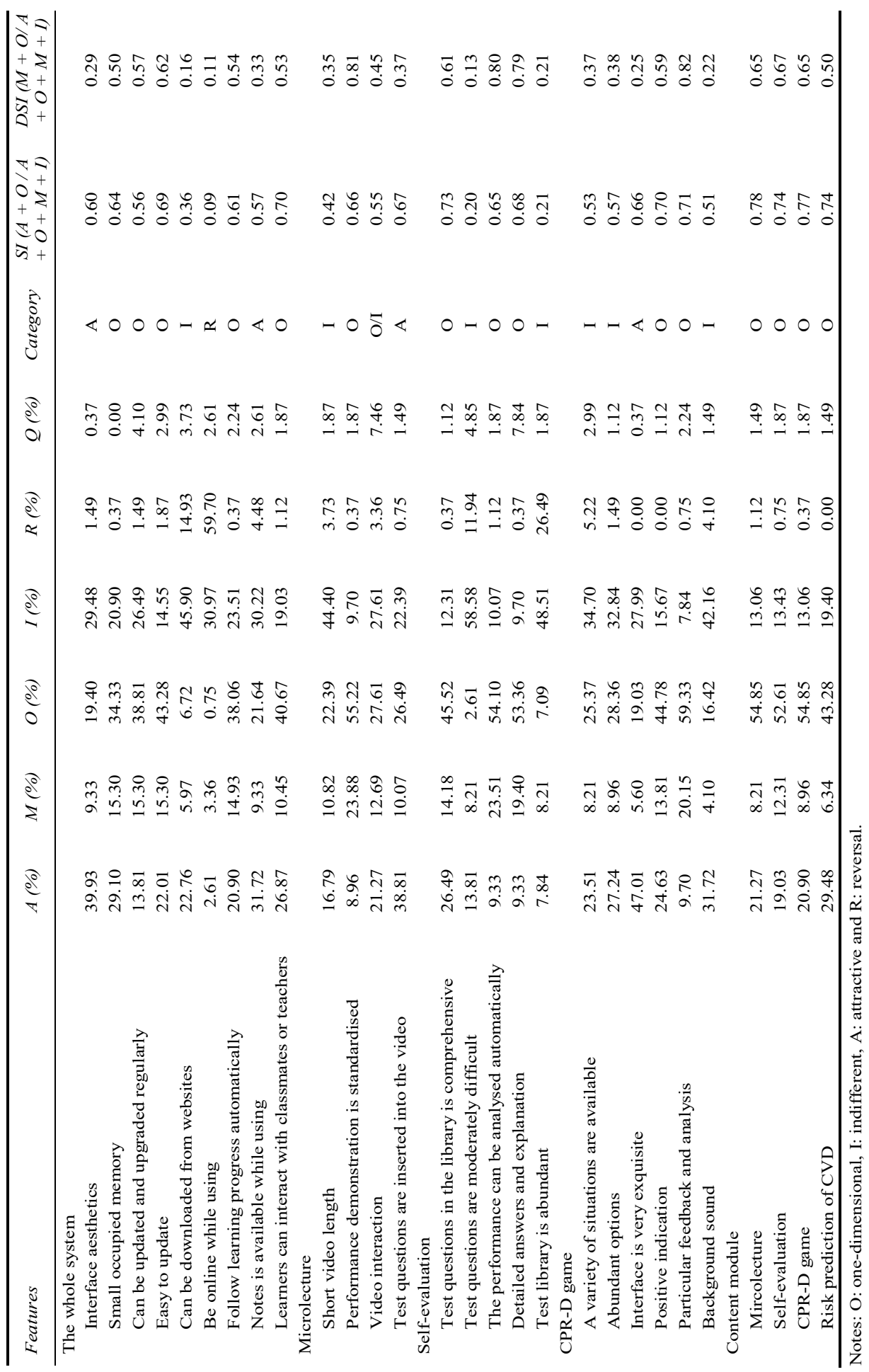


Table 4 Modified Kano categories based on statistical significance testing

\begin{tabular}{|c|c|c|c|c|c|}
\hline Features & $\begin{array}{l}\text { Most } \\
\text { frequent }\end{array}$ & $\begin{array}{l}\text { Second } \\
\text { most } \\
\text { frequent }\end{array}$ & $\begin{array}{l}\text { Chi-square } \\
\text { p-value }\end{array}$ & $\begin{array}{l}\text { Significant } \\
\text { difference* }\end{array}$ & $\begin{array}{c}\text { Final } \\
\text { category** }\end{array}$ \\
\hline \multicolumn{6}{|l|}{ The whole system } \\
\hline Interface aesthetics & A & I & 0.040 & No & A \\
\hline Small occupied memory & $\mathrm{O}$ & A & 0.283 & No & $\mathrm{O}$ \\
\hline $\begin{array}{l}\text { Can be updated and upgraded } \\
\text { regularly }\end{array}$ & $\mathrm{O}$ & $\mathrm{I}$ & 0.013 & No & $\mathrm{O}$ \\
\hline Easy to update & $\mathrm{O}$ & A & $<0.001$ & Yes & $\mathrm{O}$ \\
\hline Can be downloaded from websites & $\mathrm{I}$ & A & $<0.001$ & Yes & I \\
\hline Be online while using & $\mathrm{R}$ & $\mathrm{I}$ & $<0.001$ & Yes & $\mathrm{R}$ \\
\hline $\begin{array}{l}\text { Follow learning progress } \\
\text { automatically }\end{array}$ & $\mathrm{O}$ & I & 0.002 & Yes & $\mathrm{O}$ \\
\hline Notes is available while using & A & I & 0.756 & No & A \\
\hline $\begin{array}{l}\text { Learners can interact with } \\
\text { classmates or teachers }\end{array}$ & $\mathrm{O}$ & A & 0.006 & Yes & $\mathrm{O}$ \\
\hline \multicolumn{6}{|l|}{ Microlecture } \\
\hline Short video length & I & $\mathrm{O}$ & $<0.001$ & Yes & I \\
\hline $\begin{array}{l}\text { Performance demonstration is } \\
\text { standardised }\end{array}$ & $\mathrm{O}$ & M & $<0.001$ & Yes & $\mathrm{O}$ \\
\hline Video interaction & $\mathrm{O} / \mathrm{I}$ & A & 0.137 & No & $\mathrm{O}$ \\
\hline $\begin{array}{l}\text { Test questions are inserted into the } \\
\text { video }\end{array}$ & A & $\mathrm{O}$ & 0.013 & No & $\mathrm{O}$ \\
\hline \multicolumn{6}{|l|}{ Self-evaluation } \\
\hline $\begin{array}{l}\text { Test questions in the library is } \\
\text { comprehensive }\end{array}$ & $\mathrm{O}$ & A & $<0.001$ & Yes & $\mathrm{O}$ \\
\hline $\begin{array}{l}\text { Test questions are moderately } \\
\text { difficult }\end{array}$ & I & A & $<0.001$ & Yes & I \\
\hline $\begin{array}{l}\text { The performance can be analysed } \\
\text { automatically }\end{array}$ & $\mathrm{O}$ & M & $<0.001$ & Yes & $\mathrm{O}$ \\
\hline Detailed answers and explanation & $\mathrm{O}$ & M & $<0.001$ & Yes & $\mathrm{O}$ \\
\hline Test library is abundant & I & $\mathrm{R}$ & $<0.001$ & Yes & I \\
\hline \multicolumn{6}{|l|}{ CPR-D game } \\
\hline A variety of situations are available & I & $\mathrm{O}$ & 0.049 & No & $\mathrm{O}$ \\
\hline Abundant options & I & $\mathrm{O}$ & 0.349 & No & $\mathrm{O}$ \\
\hline Interface is very exquisite & A & I & $<0.001$ & Yes & A \\
\hline Positive indication & $\mathrm{O}$ & A & $<0.001$ & Yes & $\mathrm{O}$ \\
\hline Particular feedback and analysis & $\mathrm{O}$ & M & $<0.001$ & Yes & $\mathrm{O}$ \\
\hline Background sound & I & A & 0.047 & No & A \\
\hline \multicolumn{6}{|l|}{ Content module } \\
\hline Mircolecture & $\mathrm{O}$ & A & $<0.001$ & Yes & $\mathrm{O}$ \\
\hline Self-evaluation & $\mathrm{O}$ & A & $<0.001$ & Yes & $\mathrm{O}$ \\
\hline CPR-D game & $\mathrm{O}$ & A & $<0.001$ & Yes & $\mathrm{O}$ \\
\hline Risk prediction of CVD & $\mathrm{O}$ & $\mathrm{A}$ & 0.008 & Yes & $\mathrm{O}$ \\
\hline
\end{tabular}

Notes: *At the $90 \%$ confidence level and **based on $\mathrm{M}>\mathrm{O}>\mathrm{A}>\mathrm{I}$ rule. 
Table 5 The goal attainment of Kano QFs within CPR-D training system

\begin{tabular}{|c|c|c|c|c|}
\hline Features & $\begin{array}{l}\text { Final } \\
\text { category }\end{array}$ & Version 1.0 & Version 2.0 & $\begin{array}{l}\text { Future } \\
\text { version }\end{array}$ \\
\hline \multicolumn{5}{|l|}{ The whole system } \\
\hline Interface aesthetics & A & Unaccomplished & $\begin{array}{c}\text { Partially } \\
\text { accomplished }\end{array}$ & $\begin{array}{l}\text { Second } \\
\text { priority }\end{array}$ \\
\hline Small occupied memory & $\mathrm{O}$ & Unaccomplished & Unaccomplished & $\begin{array}{c}\text { Do not } \\
\text { accomplish }\end{array}$ \\
\hline $\begin{array}{l}\text { Can be updated and } \\
\text { upgraded regularly }\end{array}$ & $\mathrm{O}$ & Accomplished & Accomplished & Maintain \\
\hline Easy to update & $\mathrm{O}$ & Unaccomplished & Unaccomplished & First priority \\
\hline $\begin{array}{l}\text { Can be downloaded from } \\
\text { websites }\end{array}$ & I & Unaccomplished & Unaccomplished & $\begin{array}{l}\text { Second } \\
\text { priority }\end{array}$ \\
\hline Be online while using & $\mathrm{R}$ & Unaccomplished & Unaccomplished & Avoid \\
\hline $\begin{array}{l}\text { Follow learning progress } \\
\text { automatically }\end{array}$ & $\mathrm{O}$ & Unaccomplished & Unaccomplished & $\begin{array}{l}\text { Second } \\
\text { priority }\end{array}$ \\
\hline $\begin{array}{l}\text { Notes is available while } \\
\text { using }\end{array}$ & A & Unaccomplished & Unaccomplished & $\begin{array}{l}\text { Second } \\
\text { priority }\end{array}$ \\
\hline $\begin{array}{l}\text { Learners can interact with } \\
\text { classmates or teachers }\end{array}$ & $\mathrm{O}$ & Unaccomplished & Unaccomplished & $\begin{array}{l}\text { Second } \\
\text { priority }\end{array}$ \\
\hline \multicolumn{5}{|l|}{ Microlecture } \\
\hline Short video length & I & Accomplished & Accomplished & Maintain \\
\hline $\begin{array}{l}\text { Performance demonstration } \\
\text { is standardised }\end{array}$ & $\mathrm{O}$ & Accomplished & Accomplished & Maintain \\
\hline Video interaction & $\mathrm{O}$ & Accomplished & Accomplished & Maintain \\
\hline $\begin{array}{l}\text { Test questions are inserted } \\
\text { into the video }\end{array}$ & $\mathrm{O}$ & Unaccomplished & Unaccomplished & $\begin{array}{l}\text { Second } \\
\text { priority }\end{array}$ \\
\hline \multicolumn{5}{|l|}{ Self-evaluation } \\
\hline $\begin{array}{l}\text { Test questions in the library } \\
\text { is comprehensive }\end{array}$ & $\mathrm{O}$ & Accomplished & Accomplished & Maintain \\
\hline $\begin{array}{l}\text { Test questions are } \\
\text { moderately difficult }\end{array}$ & I & $\begin{array}{c}\text { Partially } \\
\text { accomplished }\end{array}$ & $\begin{array}{c}\text { Partially } \\
\text { accomplished }\end{array}$ & $\begin{array}{l}\text { Second } \\
\text { priority }\end{array}$ \\
\hline $\begin{array}{l}\text { The performance can be } \\
\text { analysed automatically }\end{array}$ & $\mathrm{O}$ & Unaccomplished & Accomplished & Maintain \\
\hline $\begin{array}{l}\text { Detailed answers and } \\
\text { explanation }\end{array}$ & $\mathrm{O}$ & Unaccomplished & Accomplished & Maintain \\
\hline Test library is abundant & I & Unaccomplished & Unaccomplished & Maintain \\
\hline \multicolumn{5}{|l|}{ CPR-D game } \\
\hline $\begin{array}{l}\text { A variety of situations are } \\
\text { available }\end{array}$ & $\mathrm{O}$ & Unaccomplished & Unaccomplished & First priority \\
\hline Abundant options & $\mathrm{O}$ & Unaccomplished & $\begin{array}{c}\text { Partially } \\
\text { accomplished }\end{array}$ & First priority \\
\hline Interface is very exquisite & A & $\begin{array}{c}\text { Partially } \\
\text { accomplished }\end{array}$ & $\begin{array}{c}\text { Partially } \\
\text { accomplished }\end{array}$ & $\begin{array}{l}\text { Second } \\
\text { priority }\end{array}$ \\
\hline
\end{tabular}


Table 5 The goal attainment of Kano QFs within CPR-D training system (continued)

\begin{tabular}{|c|c|c|c|c|}
\hline Features & $\begin{array}{l}\text { Final } \\
\text { category }\end{array}$ & Version 1.0 & Version 2.0 & $\begin{array}{l}\text { Future } \\
\text { version }\end{array}$ \\
\hline \multicolumn{5}{|l|}{ CPR-D game } \\
\hline Positive indication & $\mathrm{O}$ & Accomplished & Accomplished & Maintain \\
\hline $\begin{array}{l}\text { Particular feedback and } \\
\text { analysis }\end{array}$ & $\mathrm{O}$ & Unaccomplished & Accomplished & Maintain \\
\hline Background sound & A & Unaccomplished & $\begin{array}{c}\text { Partially } \\
\text { accomplished }\end{array}$ & $\begin{array}{l}\text { Second } \\
\text { priority }\end{array}$ \\
\hline \multicolumn{5}{|l|}{ Content module } \\
\hline Mircolecture & $\mathrm{O}$ & Accomplished & Accomplished & Maintain \\
\hline Self-evaluation & $\mathrm{O}$ & Accomplished & Accomplished & Maintain \\
\hline CPR-D game & $\mathrm{O}$ & Accomplished & Accomplished & Maintain \\
\hline Risk prediction of CVD & $\mathrm{O}$ & Accomplished & Accomplished & Maintain \\
\hline
\end{tabular}

Figure 2 The user interface (UI) and modules of CPR-D training system (see online version for colours)
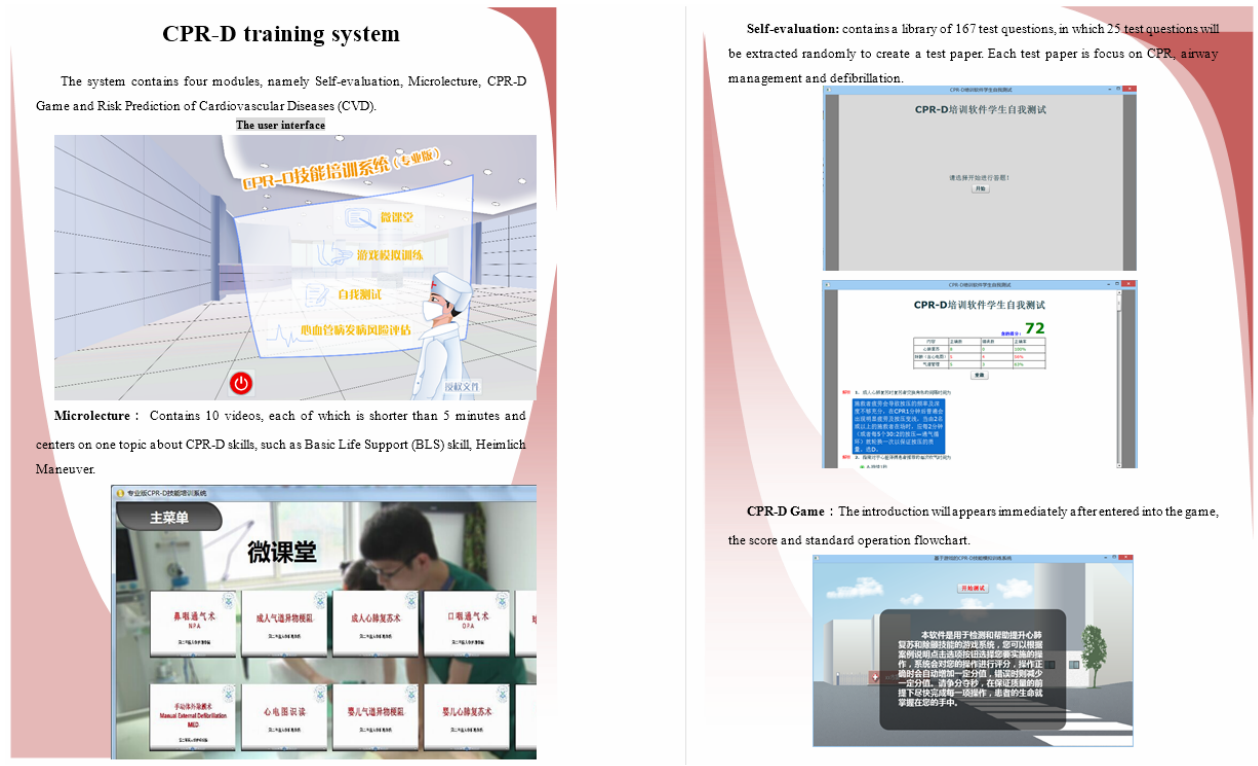

A positive customer satisfaction coefficient ranges in value from zero to one, the closer to one the value is, the higher the influence on customer satisfaction. The negative customer satisfaction operates in the same way. The customer satisfaction coefficients are plotted in Figure 3. In this matrix, the SI is on the x-axis while the DSI is on the y-axis, and the mean of SI and DSI divides the diagram into four quadrants (area I, attractive area; area II, indifferent area; area III, must-be area; area IV, one-dimensional area) (Table 6). 
Table 6 Distribution of requirements

\begin{tabular}{lcc}
\hline Quadrants & Items number & Quantity \\
\hline One-dimensional & $2,4,7,9,11,14,16,17,22,23,25,26,27,28$ & 14 \\
Must-be & $1,13,21$ & 3 \\
Indifferent & $5,6,8,10,12,15,18,19,20,24$ & 10 \\
Attractive & 3 & 1 \\
\hline
\end{tabular}

Figure 3 Customer satisfaction coefficient diagram (see online version for colours)

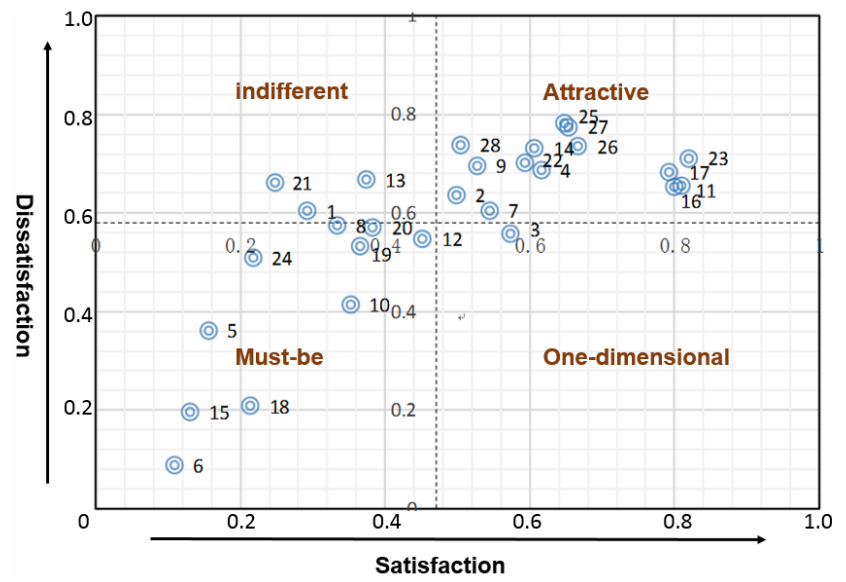

\section{Discussion}

CPR and defibrillation, the most important elements of early resuscitation for SCA, are indispensable skills for healthcare providers. Therefore, the training of CPR-D skills is of great importance. As new technology spreads, medical education with the help of devices and digital environments becomes more and more popular. Several games and softwares for CPR training, such as iResus, iCPR, viva! CPR, CPR'98, have been developed and applied in a variety of countries (Clark et al., 2000; Low et al., 2011; Semeraro et al., 2014; Semeraro et al., 2011). Very few reports about computer-based training system of CPR in China have been published, therefore, we developed the CPR-D training system to provide practical learning materials for medical staffs in China.

According to Filatro and Piconez (2004), to ensure the quality of education, a good learning management system should be dynamic, and allows modification and adaptation of the materials under study, as required by the tutor and the customer. Thus, software developers are under increasing pressure to develop software faster that not only meets a customer's requirements, but exceeds them (Cusumano and Yoffie, 1999), which makes the customer requirements very important. As Hauser and Clausing (1988) point out, customer expectation and satisfaction are of paramount importance in defining the 
service or product and its popularity. Kano model is an excellent tool of determining customer requirements for new product development and innovation, which has been used to help researchers focus on aspects that will augment product/service value and therefore increase sales and profits. In addition, the Kano model has been proved to be an effective tool. The information obtained from Kano Model analysis, specifically regarding one-dimensional and attractive attributes, provides valuable input for design and optimising process (Kano Model Analysis, 2002). Thus, the Kano model was applied to help dig customer requirements of the CPR-D training system. In this study, application of the Kano model, through a especially designed questionnaire, allowed to categorise healthcare staff training preferences of CPR-D training system into 'one dimensional', 'attractive', 'must-be', 'reversal' and 'indifferent' ones. This helped the training program designers to evaluate the impact of meeting these staff preferences on staff satisfaction with the training.

One-dimensional attributes are the key to improve quality of CPR-D training system. Of those 28 QFs derived from focus group meeting, more than half are defined as one-dimensional attributes through questionnaire survey. That is in accord with the character of Kano model, namely, of the needs customers verbalise, most will fall into the category of one-dimensional attributes (Kano Model Analysis, 2002). The willingness to use the product is closely tied to one-dimensional attributes. So it is important to meet customers' one-dimensional attributes to the greatest extent, which is the primary principle to optimise CPR-D training system. From the findings of this study, we can learn that, both the content and presentation of CPR-D training system value a lot to customers. They emphasise the content should be accurate, abundant and timely-updated, while the expression should be diversified. Moreover, customers prefer humanised design and friendly interface. What's more, they put a high value on all the four modules, indicating that the medical staffs are willing to receive diversified training. Besides, the modern training resources can draw medical staffs' attention.

Attractive attributes can surprise people, win customers' loyalty, and enhance/boost competitiveness of products. Therefore, attractive attributes should be considered of and be implemented as far as possible when optimising the CPR-D training system. The attractive attributes of this study show us that customers like fancy UI and innovative functions, such as 'notes is available while using' and 'background sound'. Besides, to provide comfort and humanised operation features can bring fantastic satisfaction.

In contrast to the feature of one-dimensional attributes, the customers' level of dissatisfaction will increase when the reversal attribute of a product is fulfilled. The only reversal attribute, namely 'be online while using', reminded us that these learning material should allow offline access. The four indifferent attributes indicate that customers were indifferent to the accessibility to the CPR-D learning system. The reason why customers were indifferent to length of micro-lecture may be that the course they received was tutor-instructed in this study, they may pay few attention to the length of the micro-lecture, and the result may be different if this training system was used for self-learning.

Besides the five categories, the customer satisfaction coefficient diagram can also provide a reference to optimising the CPR-D training system. Attributes with high SI and high DSI are located in quadrant I, which represents a possible competitive advantage. The attributes in quadrant II and those located in quadrant III do not need additional effort. The distribution of all the attributes showed that customers like simple functions, 
what's more, detailed knowledge, accuracy and timely feedback of the core learning module are important for customers.

\section{Limitations}

There are some limitations to our study. Firstly, the sample size was small, but they can represent the specific population in a certain extent. Secondly, the effectiveness of CPR-D training system was not evaluated. Since customer requirements are changing due to the progress of the world, the assessment of costumer needs is continuous process. Thus, the survey based on Kano model must be flexible and regular, the optimising plan of CPR-D training system should also be updated accordingly.

\section{Conclusions}

This study applied Kano model to optimise CPR-D training system. With the help of Kano model, 28 QFs of CPR-D training system were categorised into several attributes, which became the guide to upgrade the training system and to make further plan. The updated version meets customers' needs better, which will increase both willingness and enthusiasm to learn CPR-D skills with the self-instructor training system we developed. The CPR-D training system will make a great difference among medical staffs if it got widely spread, especially in remote area of China.

\section{References}

Abdelhamid, I.A. (2013) Application of Kano Methods and Quality Function Deployment to the Design of Quality Improvement Training Programs in Healthcare Organizations, California State University, Dominguez Hills, Ann Arbor.

Arvindakarthik, K.S., Mohan, K.K.K. and Gokul, S.E. (2013) 'QFD for the motorcycle service quality analysis and improving customer satisfaction', International Journal of Science and Research, Vol. 4, No. 11, pp.689-692.

Chen, H-C., Lee, T-R., Lin, H-Y. and Wu, H-C. (2009) 'Application of TRIZ and the Kano method to home life industry innovation', International Journal of Innovation and Learning, Vol. 7, No. 1, pp.64-84.

Chuanzi, M. (2013) 'The influence of higher professional degree education - a empirical study based on the Kano model', Journal of Higher Education Finance, Vol. 16, pp.11-16.

Clark, L.J., Watson, J., Cobbe, S.M., Reeve, W., Swann, I.J. and Macfarlane, P.W. (2000) 'CPR'98: a practical multimedia computer-based guide to cardiopulmonary resuscitation for medical students', Resuscitation, Vol. 44, No. 2, pp.109-117.

Cusumano, M.A. and Yoffie, D.B. (1999) 'Software development on internet time', Computer, Vol. 32, No. 10, pp.60-69.

Excite and Delight Your Customers by Using the Kano Model (2014) [online] https://www.agileconnection.com/article/excite-and-delight-your-customers-using-kano-model (accessed 1 November 2015).

Filatro, A. and Piconez, S.C.B. (2004) Design Instrucional Contextualizado, Senac, São Paulo.

Friedl, K.E. and O'Neil, H.F. (2013) 'Designing and using computer simulations in medical education and training: an introduction', Military Medicine, Vol. 178, No. 10, pp.1-6. 
Greif, R., Lockey, A.S., Conaghan, P., Lippert, A., de Vries, W. and Monsieurs, K.G. (2015) 'European Resuscitation Council Guidelines for Resuscitation 2015: Section 10. Education and implementation of resuscitation', Resuscitation, Vol. 95, pp.288-301.

Hauser, J.R. and Clausing, D. (1988) 'The house of quality', Harvard Business Review, Vol. 66 [online] https://hbr.org/1988/05/the-house-ofqualiVtyo (accessed 1 November 2015).

Juanes, J.A. and Ruisoto, P. (2015) 'Computer applications in health science education', Journal of Medical Systems, Vol. 39, p.97.

Kano Model Analysis (2002) [online] http://people.ucalgary.ca/ design/engg251/First\%20Year\% 20Files/kano.pdf (accessed 18 February 2016).

Lau, F. and Bates, J. (2004) 'A review of e-learning practices for undergraduate medical education', Journal of Medical Systems, Vol. 28, No. 1, pp.71-87.

Lin, C-F. (2012) 'Mobile telemedicine: a survey study', Journal of Medical Systems, Vol. 36, No. 2, pp.511-20.

Low, D., Clark, N., Soar, J. et al. (2011) 'A randomised control trial to determine if use of the iResus(c) application on a smart phone improves the performance of an advanced life support provider in a simulated medical emergency', Anaesthesia, Vol. 66, pp.255-262.

Martínez-Pérez, B., de La Torre-Díez, I. and López-Coronado, M. (2015) 'Privacy and security in mobile health apps: a review and recommendations', Journal of Medical Systems, Vol. 39, No. 1, pp.1-8.

Matzler, K. and Hinterhuber, H.H. (1998) 'How to make product development projects more successful by integrating Kano's model of customer satisfaction into quality function deployment', Technovation, Vol. 18, No. 1, pp.25-38.

Munagavalasa, C. (2014) Excite and Delight Your Customers by Using the Kano Model.

Rashid, M.M., Tamaki, J., Sharif Ullah, A.M.M. and Kubo, A. (2010) 'A proposed computer system on Kano model for new product development and innovation aspect: a case study is conducted by an attractive attribute of automobile', International Journal of Engineering, Science and Technology, Vol. 2, No. 9, pp.1-12.

Rodrigues, R.C.V. and Peres, H.H.C. (2013) 'An educational software development proposal for nursing in neonatal cardiopulmonary resuscitation', Revista da Escola de Enfermagem da USP, Vol. 47, No. 1, pp.235-241.

Sauerwein, E., Bailom, F., Matzler, K. and Hinterhuber, H.H. (1996) 'The Kano model: how to delight your customers', International Working Seminar on Production Economics, Innsbruck, pp.313-327.

Semeraro, F., Frisoli, A., Ristagno, G. et al. (2014) 'Relive: a serious game to learn how to save lives', Resuscitation, Vol. 85, No. 7, pp.109-110.

Semeraro, F., Taggi, F., Tammaro, G., Imbriaco, G., Marchetti, L. and Cerchiari, E.L. (2011) 'iCPR: a new application of high-quality cardiopulmonary resuscitation training', Resuscitation, Vol. 82, No. 4, pp.436-441.

Sireli, Y., Kauffmann, P. and Ozan, E. (2007) 'Integration of Kano's model into QFD for multiple product design', IEEE Transactions on Engineering Management, Vol. 54, pp.380-390.

Wu, H-H., Tang, Y-T. and Shyu, J-W. (2010) 'An integrated approach of Kano's model and importance-performance analysis in identifying key success factors', African Journal of Business Management, Vol. 4, p.3238. 